\title{
A Single Nucleotide Substitution Introduces a Premature Termination Codon into the Androgen Receptor Gene of a Patient with Receptor-negative Androgen Resistance
}

\author{
M. Marcelli, W. D. Tilley, C. M. Wilson, J. D. Wilson, J. E. Griffin, and M. J. McPhaul \\ Department of Internal Medicine, The University of Texas Southwestern Medical Center at Dallas, \\ Dallas, Texas 75235-8857
}

\begin{abstract}
Mutations of the androgen receptor that impair the action of $5 \alpha$-dihydrotestosterone and testosterone result in abnormal male sexual development. The definition of the organization of the androgen receptor gene has permitted us to examine its structure in nine patients with androgen resistance that exhibit absent $5 \alpha$-dihydrotestosterone binding in cultured fibroblasts (receptor-negative androgen resistance). Using labeled probes specific for each individual coding exon, we find no gross rearrangements, insertions, or deletions of the androgen receptor gene in these patients. To analyze the genetic defect in these receptor-negative patients, we used the polymerase chain reaction to amplify each individual exon of the androgen receptor gene in nine affected patients. In all patients, the size of each amplified exon segment was identical to that in normal individuals. The nucleotide sequence of the entire coding region of the androgen receptor was determined in one of these patients. A single nucleotide substitution was identified that results in a premature termination codon in exon 6 at amino acid 794. $S_{1}$ nuclease protection assays demonstrated that normal levels of androgen receptor $\mathrm{mRNA}$ are present in skin fibroblasts of this patient. Transfection of a mutated androgen receptor cDNA containing a termination codon at position 794 into eukaryotic cells resulted in formation of a normal amount of receptor protein, as indicated by immunoblotting, but the expressed protein does not bind $5 \alpha$-dihydrotestosterone. These findings suggest that the presence of a premature termination codon at amino acid 794 of the androgen receptor is the cause of androgen resistance in this patient. (J. Clin. Invest. 1990. 85:15221528.) androgens $\bullet$ receptor $\bullet$ mutations $\bullet$ sexual development
\end{abstract}

\section{Introduction}

The actions of testosterone and $5 \alpha$-dihydrotestosterone are crucial to the development of the normal male phenotype.

This work has been reported in abstract form (1989. The Endocrine Society's 71st Annual Meeting, Seattle, WA, June 21-24. 625. [Abstr.]).

Address reprint requests to Dr. M. J. McPhaul, Department of Internal Medicine, University of Texas SW Medical Center, 5323 Harry Hines Blvd., Dallas, TX 75235-8857.

Received for publication 27 September 1989 and in revised form 21 December 1989.

J. Clin. Invest.

(c) The American Society for Clinical Investigation, Inc. 0021-9738/90/05/1522/07 \$2.00

Volume 85, May 1990, 1522-1528
Patients with resistance to these hormones exhibit a wide spectrum of abnormal sexual phenotypes, ranging from phenotypic women to undervirilized but infertile men (1). The effects of androgens during normal development are mediated through a specific protein, the androgen receptor, which is a member of the steroid/thyroid hormone receptor gene family. The androgen receptor has been characterized in a number of patients with androgen resistance, and the abnormalities of sexual development have been correlated in many instances with altered physical properties of the androgen receptor protein. These properties encompass a wide spectrum from subtle differences in thermolability to the complete absence of specific androgen binding (receptor-negative androgen resistance) and are inherited as X-linked traits.

Several groups have reported the isolation and characterization of cDNA clones encoding the human androgen receptor (2-5), making it possible to elucidate the molecular defects causing androgen resistance. To this end, Brown et al. have reported a patient in whom the fundamental defect was a deletion of a segment of the androgen receptor gene (6). To ascertain whether deletions of segments of the androgen receptor gene are a common cause of androgen resistance, we have examined in detail the structure of the gene in nine unrelated patients with receptor-negative androgen resistance. In these patients, the structure of the androgen receptor gene is intact, implying that subtle alterations within the gene must be responsible for their androgen resistance. We determined the nucleotide sequence of the coding segment of the androgen receptor gene in one of these patients and found that a single nucleotide substitution has occurred. This mutation predicts the formation of a truncated receptor protein that is unable to bind $5 \alpha$-dihydrotestosterone.

\section{Methods}

Cell culture. Fibroblasts established from explants from foreskin or genital skin biopsies were grown in Dulbecco's modified essential medium supplemented with $10 \%$ fetal bovine serum and $1 \%$ penicillin and streptomycin. All of the patients examined in this study have been characterized by the monolayer binding of $\left[{ }^{3} \mathrm{H}\right] 5 \alpha$-dihydrotestosterone and have been classified as having receptor-negative androgen resistance, i.e., $<4 \mathrm{fmol} / \mathrm{mg}$ protein of specific $5 \alpha$-dihydrotestosterone binding (1). The androgen receptor from one patient, N750, was chosen for a more detailed sequence analysis. The N750 fibroblast strain was obtained from a biopsy of labia majora from a 14-yr-old woman with the syndrome of complete testicular feminization. The woman is a patient of Drs. Joanne Bodurtha and W. Glen Hurt (Medical College of Virginia, Richmond, VA) and has been reported previously (7) $5 \alpha$-reductase activity was measured in this fibroblast strain according 
to the method of Leshin et al. (8) and was $18.4 \mathrm{pmol} / \mathrm{mg}$ protein (normal $>2$ ). The androgen receptor level assayed in monolayer culture was $1.1 \mathrm{fmol} / \mathrm{mg}$ protein $/ \mathrm{h}$ (normal $>15$ ).

DNA and RNA preparation. DNA was prepared from confluent fibroblast cultures by modifications of standard techniques (9). RNA was prepared by homogenization of fibroblast cell pellets in $4.5 \mathrm{M}$ guanidinium isothiocyanate and step gradient centrifugation through a cushion of $5.7 \mathrm{M}$ cesium chloride (10).

Southern analysis. Samples of DNA were digested to completion with the restriction endonuclease Eco RI and run on $0.8 \%$ agarose gel. After transfer to a nylon membrane (Zetaprobe; Bio-Rad Laboratories, Richmond, CA), the filters were cross-linked using ultraviolet light (Stratalinker; Stratagene Cloning Systems, La Jolla, CA) and baked for $2 \mathrm{~h}$ at $80^{\circ} \mathrm{C}$. Prehybridization was performed in buffer containing $7 \%$ SDS and $10 \mathrm{mM}$ sodium phosphate buffer $(\mathrm{pH} 7.0)$ for $2 \mathrm{~h}$ at $68^{\circ} \mathrm{C}$. Hybridization was performed in an aliquot of the same buffer, containing $1 \times 10^{6} \mathrm{cpm} / \mathrm{ml}$ of exon-specific probe $\left(\sim 5 \times 10^{8} \mathrm{cpm} / \mu \mathrm{g} \mathrm{sp}\right.$ act of DNA). After hybridization, the blots were washed in $0.1 \times$ SSC $0.1 \% \mathrm{SDS}$ at $68^{\circ} \mathrm{C}$, and autoradiographed at $-80^{\circ} \mathrm{C}(11)$.

The exon-specific probes were derived from genomic DNA and cDNA fragments. For exons 1,3 , and 4 , the probes were generated by amplification of regions of the androgen receptor cDNA (nucleotides 494-933 [the cDNA coordinates used throughout the text refer to those employed in Reference 2] for exon 1, and nucleotides 1,9222,326 for exons 3 and 4). These regions of the androgen receptor cDNA were amplified by the polymerase chain reaction $(\mathrm{PCR})^{1}(12)$ as described below, using oligonucleotide primers derived from the sequence of the androgen receptor cDNA (2). Exons 7 and 8 were visualized using a 498-bp Eco RI restriction endonuclease fragment of the androgen receptor cDNA (nucleotides 2,563-3,061). Exons 2, 5, and 6 were identified by hybridization with three different DNA fragments resulting from the amplification of segments of the androgen receptor gene from genomic DNA. Each probe was $\sim 250 \mathrm{bp}$ in length and contained the appropriate exon and 50-100 nucleotides of flanking intron sequence.

Amplification of the androgen receptor gene using the polymerase chain reaction. Amplification of individual segments of the androgen receptor gene was performed using the PCR as described (12). Oligonucleotides were synthesized based on the nucleotide sequence of the regions flanking the individual coding exon segments (Tilley, W. D., M. Marcelli, and M. J. McPhaul, unpublished observations). For exons 2-8, pairs of these oligonucleotides were annealed to the genomic DNA of each patient. The large segment comprising exon 1 was amplified using four overlapping sets of oligonucleotides. The amplified segments ranged from $250-400 \mathrm{bp}$ in size. The amplification of each exon was performed with 35 amplification cycles (annealing and extension at $68^{\circ} \mathrm{C}$ for $6 \mathrm{~min}$, denaturation at $95^{\circ} \mathrm{C}$ for $1 \mathrm{~min}$ ), by using the Taq I DNA polymerase (Cetus Corp., Emeryville, CA) and the DNA Thermo Cycler (Perkin-Elmer Cetus, Emeryville, CA).

While this strategy was employed for most sections of the androgen receptor open-reading frame, the region encoding the glycine homopolymeric segment, nucleotides $1,504-1,572$, was resistant to reproducible amplification directly from samples of genomic DNA. For this reason, a genomic library was constructed from the genomic DNA of patient N750. A sample of genomic DNA was completely digested with the restriction endonuclease Eco RI and fractionated on a $0.7 \%$ agarose gel. The fragments of 9-23 kb were isolated, purified, and ligated into the cloning vector EMBL4 digested with the restriction endonuclease Eco RI (13). The resulting library (complexity of $1 \times 10^{6}$ recombinants) was screened with a labeled fragment of exon 1 . Two positive clones ( $\lambda \mathrm{gc} 750-1$ and $\lambda \mathrm{gc} 750-2)$ were isolated and purified to homogeneity. The segment encoding the glycine-rich region of the

1. Abbreviation used in this paper: PCR, polymerase chain reaction. androgen receptor of patient N750 was amplified from a 1- $\mu \mathrm{g}$ sample of $\lambda \mathrm{gc750-1}$ DNA and sequenced as described above.

Nucleotide sequencing. Artificial Eco RI restriction endonuclease cleavage sites were included at the 5 terminus of each oligonucleotide used in the amplification of exons $1-5,7$, and 8 of the androgen receptor gene. This permitted the amplified exon fragments to be purified and directly ligated into M13-sequencing vectors. Exon 6 was amplified and cloned in an analogous manner using artificial Bam HI endonuclease cleavage sites at the oligonucleotide termini. Nucleotide sequence analysis of the amplified exons was performed using the dideoxy termination method of Sanger et al. (14).

Site-directed mutagenesis. The point mutation detected from the sequencing of the androgen receptor gene of patient N750 was incorporated into an oligonucleotide corresponding to nucleotides 2,5332,563 of the human androgen receptor cDNA nucleotide sequence (2) and that contained an artificial $\mathrm{Xba} I$ restriction endonuclease cleavage site at its $5^{\prime}$ terminus (TTT TCT AGA CCT GGG GGG TGA TTT GGA GTC ATC CAA ACTC; the site of the point mutation is underlined). This oligonucleotide and a second oligonucleotide of opposite polarity that spans nucleotides 1,843-1,868 (GGA GAT GAA GCT TCT GGG TGT CAC T) were annealed to a $0.1-\mu \mathrm{g}$ sample of the human androgen receptor cDNA. After amplification using the PCR, the resulting fragment was isolated, purified, and digested with the restriction endonucleases, Hind III and Xba I. As the androgen receptor cDNA that we have previously characterized contains only a single internal Hind III cleavage site, and the expression vector CMV3 contains only a single $\mathrm{Xba} I$ restriction endonuclease cleavage site flanking the $3^{\prime}$ terminus of the inserted cDNA, it was possible to remove the $3^{\prime}$ terminus of the normal androgen receptor (nucleotides 1,850-3,061) by digestion with the restriction endonucleases Hind III and Xba I, and replace this fragment with the amplified segment containing the recreated termination codon in place of amino acid 794. Thus, this plasmid, designated hARmut750, contains an androgen receptor cDNA that is shortened at its $\mathbf{3}^{\prime}$ terminus but that contains the $(G \rightarrow A)$ point mutation identified in patient $\mathrm{N} 750$ at nucleotide 2,544 . The nucleotide sequence of this mutated segment was confirmed by dideoxy sequencing.

RNA probe synthesis. A 713-bp DNA fragment (nucleotides $1,850-2,563$ ) of the human androgen receptor gene was subcloned into the plasmid vector, BSKSM13+ (Stratagene). After linearization with the restriction endonuclease Hind III, in vitro transcription was performed using the T7 polymerase, as described by the manufacturer, in the presence of $4 \mu \mathrm{M}$ each of labeled $\left[\alpha^{32} \mathrm{P}\right] \mathrm{rUTP}(800 \mathrm{Ci} / \mathrm{mmol} \mathrm{sp}$ act $)$ (Amersham Corp., Arlington Heights, IL) and unlabeled rUTP. After synthesis, the DNA template was digested with RNAse-free DNAse (RIQ DNASE; Promega Biotec, Madison, WI) and the unincorporated nucleotides were removed by ammonium acetate precipitation.

$S_{1}$ nuclease protection. $S_{1}$ nuclease protection assays were performed using a protocol similar to that of Burke et al. (15). Approximately $10^{5} \mathrm{cpm}$ of the purified uniformly labeled antisense RNA probe was coprecipitated with $25 \mu \mathrm{g}$ RNA samples, rinsed with ethanol, and dried. The samples were resuspended in a solution containing $0.4 \mathrm{M}$ $\mathrm{NaCl}, 0.04 \mathrm{M}$ Pipes (pH 6.5), $1 \mathrm{mM}$ EDTA, and $62.5 \%$ deionized formamide and incubated for $16 \mathrm{~h}$ at $45^{\circ} \mathrm{C}$. After hybridization, $300 \mu \mathrm{l}$ of ice-cold $S_{1}$ buffer $(0.025 \mathrm{M} \mathrm{NaCl}, 30 \mathrm{mM}$ sodium acetate [pH 4.5], 1 $\mathrm{mM}$ zinc sulfate, and $5 \%$ glycerol) was added. Nuclease digestion was performed with $4,000 \mathrm{U}$ of $\mathrm{S}_{1}$ nuclease at $42^{\circ} \mathrm{C}$ for $1 \mathrm{~h}$. Digestion was terminated by the addition of $15 \mu \mathrm{l}$ of buffer containing $0.5 \mathrm{M}$ Tris ( $\mathrm{pH}$ 8.0), $0.25 \mathrm{M}$ EDTA, and $5 \mu \mathrm{g}$ of transfer RNA. The samples were extracted with phenol/chloroform $(1: 1)$, precipitated at $-20^{\circ} \mathrm{C}$ after addition of $1 \mathrm{ml}$ of chilled ethanol, and then resuspended and precipitated with ammonium acetate two times. After the final precipitation, the samples were washed in ethanol, dried, resuspended in $90 \%$ formamide, and analyzed on a denaturing $5 \%$ polyacrylamide gel containing $8 \mathrm{M}$ urea. 
Cell transfection. The expression plasmids hAR3.1 and hARmut 750 contain the complete androgen receptor cDNA (2) and mutated receptor cDNA clones, respectively, in the expression vector CMV3. On day 1, confluent cultures of COS cells were trypsinized and resuspended in electroporation buffer $(20 \mathrm{mM}$ Hepes pH 7.05, 137 $\mathrm{mM} \mathrm{NaCl}, 5 \mathrm{mM} \mathrm{KCl}, 0.7 \mathrm{mM} \mathrm{Na}_{2} \mathrm{HPO}_{4}$, and $6 \mathrm{mM}$ Dextrose). $10^{7}$ cells were resuspended in $1 \mathrm{ml}$ of this buffer containing $20 \mu \mathrm{g} / \mathrm{ml}$ of either hAR3.1 or hARmut750. Electroporation was accomplished by the discharge of $225 \mathrm{~V}$ through the cell suspension (16). After an additional 5-min incubation at $0^{\circ} \mathrm{C}$, the electroporated cells were then plated into dishes and cultured at $37^{\circ} \mathrm{C}$. Cultures were employed on day 3 for monolayer binding studies or harvested for Western analysis.

Binding assays. $3 \mathrm{~d}$ after transfection, monolayer cultures were incubated with $2 \mathrm{nM}\left[1,2,4,5,6,7-{ }^{3} \mathrm{H}\right] 5 \alpha$-dihydrotestosterone $(107 \mathrm{Ci} /$ mmol, Amersham Corp.) in minimal essential medium containing $10 \%$ bovine serum albumin for $1 \mathrm{~h}$ at $37^{\circ} \mathrm{C}$. Monolayers were washed twice with $5 \mathrm{ml}$ of ice-cold Tris saline and removed from the culture dishes by trypsinization. The cells were pelleted and washed twice with 5-ml aliquots of ice-cold Tris saline. The washed cell pellets were

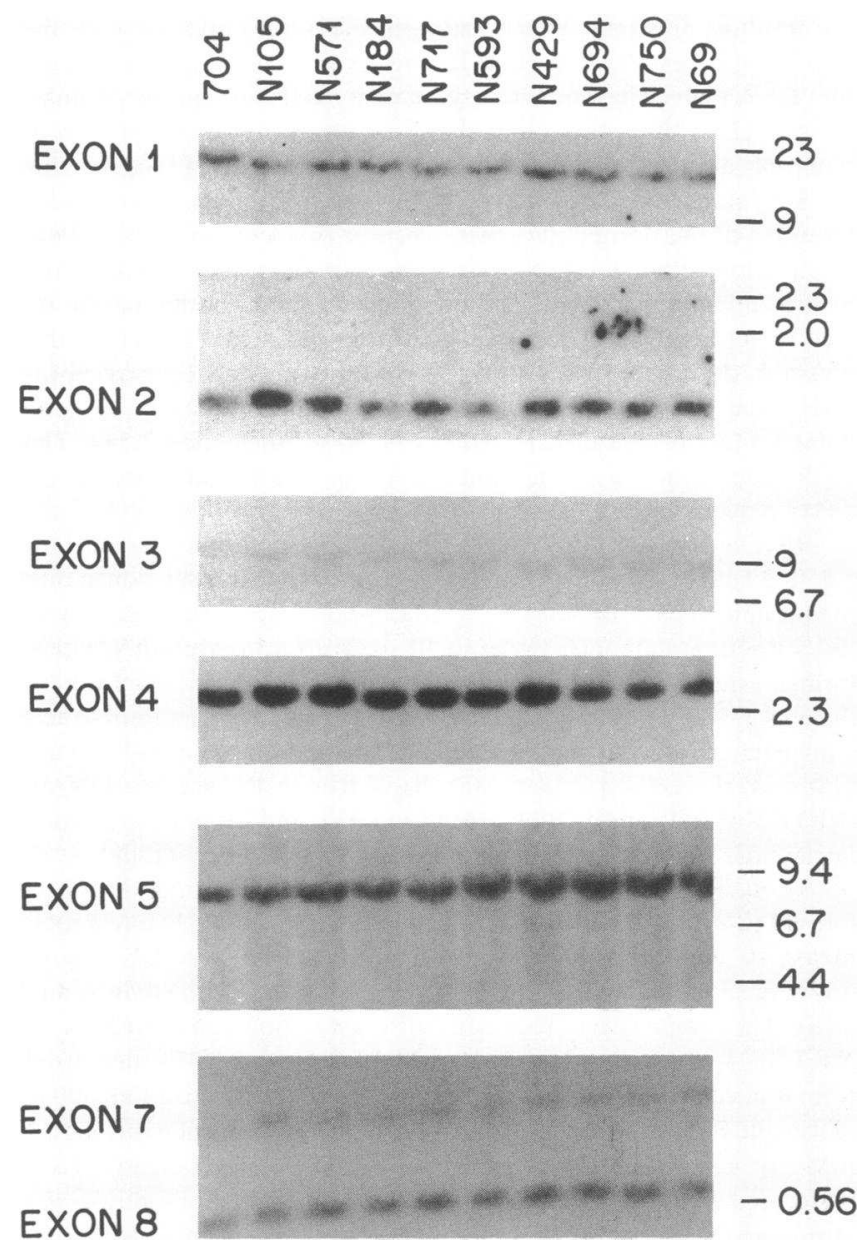

Figure 1. Genomic Southern analysis of nine patients with receptornegative complete androgen resistance. 20- $\mu$ g aliquots of genomic DNA from nine patients digested with the restriction endonuclease Eco RI were analyzed. The filters were probed with labeled probes specific for the individual exons, as shown in the left margin. Exon 6 is contained on the same fragment as exon 5. (704 is prepared from normal control fibroblasts.) Sizes in kilobases are shown to the right. resuspended in distilled water and sonicated (17). Aliquots were removed for scintillation counting and for protein determination by the method of Lowry et al. (18).

Immunoblotting. SDS-PAGE was carried out in $7.5 \%$ gels according to the method of Laemmli (19) using 30- $\mu$ l samples containing 93 $\mu \mathrm{g}$ protein from $\mathrm{COS}$ cells transfected with androgen receptor cDNA or $99 \mu \mathrm{g}$ protein from COS cells transfected with the artifically constructed cDNA containing the premature termination codon. Immunoblots were prepared as described by Harris et al. (20). Antisera were produced as described by Green et al. (21) by immunizing rabbits with keyhole limpet hemocyanin linked to synthetic peptides containing either the carboxyl-(COOH-) terminal 20 -amino acid sequence or the amino-( $\left.\mathrm{NH}_{2}-\right)$ terminal 21-amino acid sequence of the human androgen receptor protein. Antipeptide antibodies were purified by affinity chromatography on columns of peptide linked to $\mathrm{CNBr}$-activated Sepharose 4B according to the manufacturer's description (Pharmacia Fine Chemicals, Piscataway, NJ). Affinity-purified anti$\mathrm{N}$-terminal antibodies from rabbit $\mathrm{T} 687$ were used at a final dilution of 1:25 (18 $\mu \mathrm{g}$ protein/ml). Affinity-purified anti-COOH-terminal antibodies from rabbit $\mathrm{R} 489$ were used at a final dilution of 1:200 (3 $\mu \mathrm{g}$ protein/ml). ${ }^{125} \mathrm{I}$-labeled goat anti-rabbit IgG $\mathrm{F}\left(\mathrm{ab}^{\prime}\right)_{2}$ (New England Nuclear, Boston, MA) was used to detect specifically bound antibody.

\section{Results}

Southern analysis. As patients with the receptor-negative form of androgen resistance have undetectable levels of $\left[{ }^{3} \mathrm{H}\right] 5 \alpha$-dihydrotestosterone binding, we first examined the structure of the androgen receptor gene in these individuals to assess the presence and integrity of each coding exon. Fig. 1 shows the

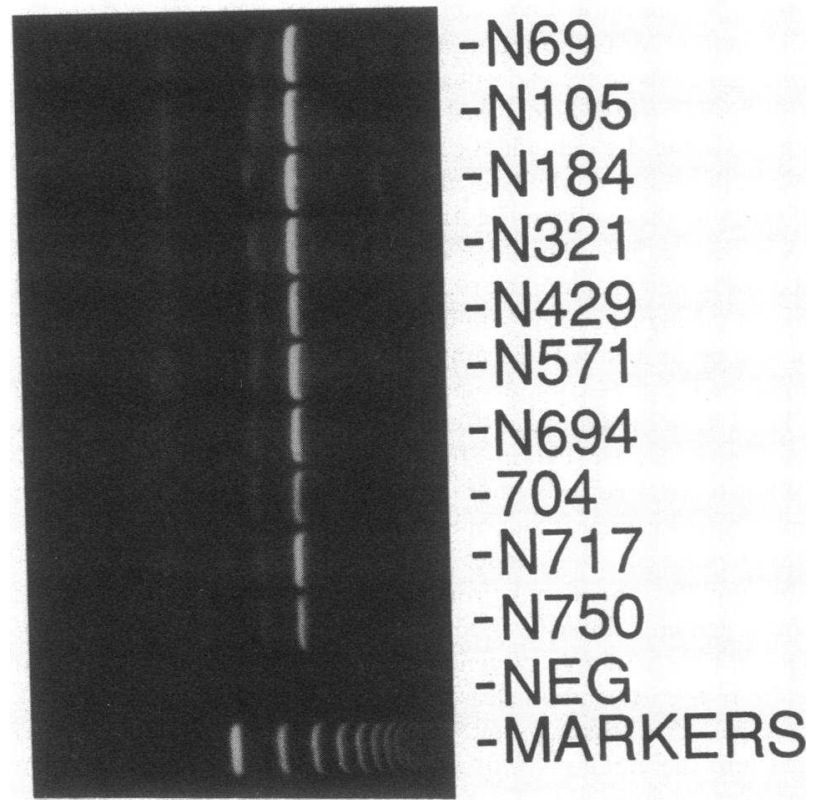

Figure 2. Analysis of exon 8 of the androgen receptor gene using the PCR. Amplification of exon 8 was performed employing an oligonucleotide pair flanking the coding segment of exon 8 . The reaction products were electrophoresed on a $2 \%$ agarose gel, stained, and photographed. (Sample 704 is prepared from normal control fibroblasts.) Size markers are shown below. 
pattern visualized by genomic Southern analysis of nine patients affected by the receptor-negative form of complete testicular feminization. In each of the mutants, a number of restriction fragments are identified, each corresponding to a specific exon, the exception being the band indicated as exon 6 , which also contains a large portion of exon 5 . The patterns visualized in the DNA prepared from the patients are indistinguishable from that of the normal control (704 is normal genital skin fibroblasts), suggesting that in each of the receptor-negative patients all eight exons of the androgen receptor gene are present and contain no major deletions or rearrangements.

Sizing of the PCR amplification products. The results of the Southern analysis implied that the alterations in these nine receptor-negative patients were not due to large deletions or insertions within the androgen receptor gene. To examine the structure of the individual exons in greater detail, oligonucleotide pairs bounding individual coding segments were used to amplify the androgen receptor gene as 11 distinct fragments, 7 corresponding to exons 2-8 and 4 overlapping fragments of exon 1 . These amplified segments were then examined by agarose gel electrophoresis. An example of one experiment that examines exon 8 is shown in Fig. 2. The size of each of the amplified fragments is identical and agrees with the size produced using genomic DNA from normal controls. In other experiments, we have obtained the same results for the remainder of the eight coding exons of the androgen receptor gene (data not shown). In each case, the amplified segment was identical in each of nine mutants and indistinguishable from samples prepared from normal controls. As the sizes of these amplified exon fragments are $\sim 200-300$ nucleotides long, the resolution of this method is much finer than genomic Southern analysis and implies that any alterations within the androgen receptor coding region in these patients must be quite small.

Sequencing of the androgen receptor gene in patient $N 750$. To investigate the nature of the mutations, we determined the complete nucleotide sequence of the coding segments of the androgen receptor gene in one of these patients, designated N750. This analysis was performed by amplification of 11 fragments of the androgen receptor gene from genomic DNA. The oligonucleotides employed in this analysis contained artificial Eco RI or Bam HI restriction endonuclease cleavage sites at their termini, allowing the amplified segments to be subcloned into M13 and sequenced. This analysis reveals three differences between the nucleotide sequence of the androgen receptor of mutant $\mathrm{N} 750$ and that which we previously pub- lished for the normal human androgen receptor (2). First, two nucleotides (Nos. 793 and 794) are inverted. Reexamination of this region in our original normal androgen receptor cDNA reveals that the sequence detected in N750 is correct. This alteration results in the presence of an alanine residue at position 211 in the predicted amino acid sequence rather than an arginine as we previously reported. Second, the N750 androgen receptor contains 21 glutamine residues between amino acids 338 and 354, in contrast to the 20 residues in our original sequence. It is notable that this segment appears to be truly polymorphic among normal individuals as the sequences reported to date for this segment have contained 17 (4), 21, 25 (3), and 20 (22) glutamine residues. Finally, our analysis revealed a single base substitution (guanosine to adenosine) at position 2,544, as shown in Fig. 3. This point mutation, which has been detected in three separate amplification reactions of exon 6 in patient N750, but not in control samples, results in the conversion of the triplet encoding tryptophan 794 into a termination codon. The position of this termination codon within the linear structure of the androgen receptor is shown schematically in Fig. 4. No other sequence polymorphism was identified in the remainder of the open reading frame.

$S_{1}$ nuclease protection assay. To determine whether a truncated androgen receptor could explain the androgen resis-

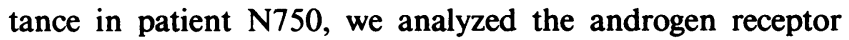
mRNA in fibroblasts using an $S_{1}$ nuclease protection assay. The results of this analysis are shown in Fig. 5. The quantity of androgen receptor mRNA in fibroblasts from patient N750 is similar to that in normal control fibroblasts (strain 704) but less than that in the human prostate carcinoma cell line, LNCaP. A similar analysis has also been performed using other portions of the androgen receptor gene, including the $5^{\prime}$ noncoding region of the androgen receptor gene and a segment of exon 1 with similar results (data not shown). These results imply that near normal levels of androgen receptor mRNA are produced in fibroblasts of patient N750.

The truncated androgen receptor does not bind dihydrotestosterone. To determine whether the truncated androgen receptor predicted for patient N750 would exhibit defective binding of $5 \alpha$-dihydrotestosterone, we transfected the normal androgen receptor (hAR3.1) and the mutated form of the androgen receptor (hARmut750) into COS cells as described in Methods. Introduction of the normal cDNA into COS cells results in high levels of specific androgen binding in monolayer binding assays as shown in Table I. By contrast, no specific binding of $5 \alpha$-dihydrotestosterone is detected after trans-

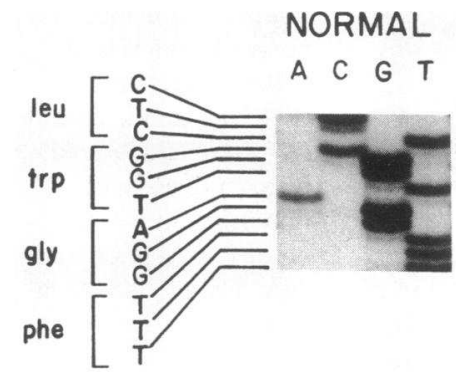

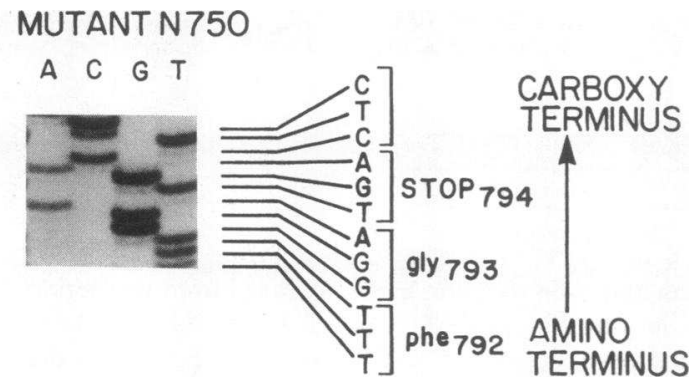

Figure 3. Nucleotide sequence analysis of the androgen receptor gene identified a single nucleotide substitution in exon 6 of patient N750. The single base change of guanosine to adenosine results in a premature termination codon in place of amino acid 794. 
Table I. $\left[{ }^{3} \mathrm{H}\right] 5 \alpha$-Dihydrotestosterone Binding in COS Cells Transfected with the Normal (hAR3.1) and Mutant (hARmut750) Androgen Receptor cDNAs

\begin{tabular}{ccc}
\hline Plasmid & Steroid & $\begin{array}{c}{\left[{ }^{3} \mathrm{H}\right] 5 \alpha \text { - }} \\
\text { dihydrotestosterone- } \\
\text { bound }\end{array}$ \\
\hline hAR3.1 & & fmol/mg protein \\
& {$\left[{ }^{3} \mathrm{H}\right] 5 \alpha$-dihydrotestosterone } & 222 \\
& {$\left[{ }^{3} \mathrm{H}\right] 5 \alpha$-dihydrotestosterone } & 20 \\
& + excess unlabeled $5 \alpha-$ & \\
hARmut750 & dihydrotestosterone & 12 \\
& {$\left[{ }^{3} \mathrm{H}\right] 5 \alpha$-dihydrotestosterone } & \\
& {$\left[{ }^{3} \mathrm{H}\right] 5 \alpha$-dihydrotestosterone } \\
& + excess unlabeled $5 \alpha$ - & \\
& dihydrotestosterone & \\
\end{tabular}

COS cells were electroporated with either the cDNA encoding the native androgen receptor (hAR3.1) or the mutated androgen receptor (hARmut750) on day 1. On day 3, duplicate monolayer cultures were incubated with $2 \mathrm{nM}\left[{ }^{3} \mathrm{H}\right] 5 \alpha$-dihydrotestosterone for $1 \mathrm{~h}$ at $37^{\circ} \mathrm{C}$ in the presence or absence of $200 \mathrm{nM} 5 \alpha$-dihydrotestosterone. The monolayers were washed twice with $5 \mathrm{ml}$ of ice-cold Tris saline and removed from the culture dishes by trypsinization. The cells were pelleted and washed twice with 5-ml aliquots of ice-cold Tris saline. Samples were disrupted by sonication in distilled water and aliquots removed for scintillation counting and protein determination.

fection of the mutated androgen receptor cDNA into COS cells. This defective binding does not appear to be due to absence of the mutant receptor protein as shown by immunoblotting (Fig. 5). Furthermore, the immunoblot analysis indicates that the truncated receptor protein is $\sim 11 \mathrm{kD}$ smaller than the native receptor and is detected by an antibody directed against the amino terminal but not by an antibody directed to the carboxy terminal segment of the human androgen receptor.

\section{Discussion}

The androgen receptor gene from nine unrelated patients with the receptor-negative form of complete testicular feminization does not contain any major structural deletions or rearrangements. This is evident from Southern analysis of genomic DNA and by sizing on agarose gels of the products of PCR

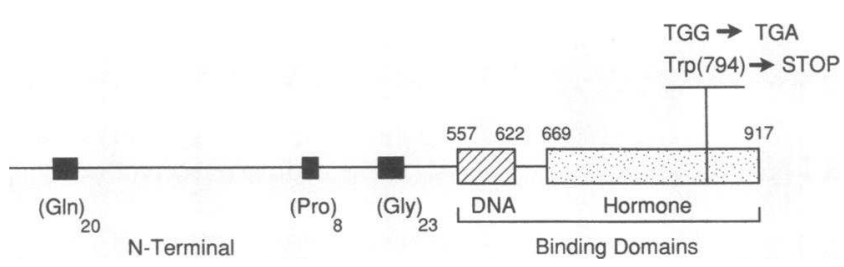

Figure 4. Schematic structure of the human androgen receptor. The figure indicates the position of the single base substitution relative to the presumed functional domains of the androgen receptor. amplification of each individual exon. Thus, the genetic alterations in this group of patients must be very small defects, such as single point mutations.

The nature of the small alterations causing receptor-negative androgen resistance would be expected to include a number of different types of mutations that would impair the function of the androgen receptor. The nucleotide sequence analysis reported here reveals a single point mutation in the segment of the androgen receptor that corresponds to the hormonebinding domain of other steroid receptors (23). This nucleotide substitution introduces a premature termination codon at amino acid 794 that would remove the 122 carboxy terminal amino acids of the androgen receptor protein. On the basis of studies on the estrogen (24) and glucocorticoid (25-27) receptors, this truncation would be expected to eliminate the hormone binding and transcriptional activation functions of the androgen receptor protein. In keeping with this expectation, no specific androgen binding is detectable in cells transfected with the cDNA containing the termination codon at amino acid 794, even though Western analysis demonstrates that the mutant androgen receptor is present in cells transfected with the mutated form of the androgen receptor cDNA. Furthermore, the Western analysis indicated that the mutant androgen receptor protein expressed in COS cells is $\sim 11 \mathrm{kD}$ smaller than the native receptor as predicted by the location of the point mutation in the androgen receptor gene. Similar truncations of the vitamin D receptor have been reported by Ritchie (28) who reported three patients in whom a premature termination codon in the gene encoding the vitamin $D$ receptor caused vitamin $\mathrm{D}$ resistance.

The mutation that we have detected in patient $N 750$ could act solely by altering the primary amino acid sequence of the receptor protein or by affecting the level of androgen receptor mRNA. For this reason, we examined the levels of androgen receptor mRNA using a highly sensitive nuclease protection assay. The demonstration of comparable quantities of androgen receptor mRNA in normal fibroblasts and in fibroblasts from patient N750 suggests that truncation of the androgen receptor protein must be the principal alteration in this patient.

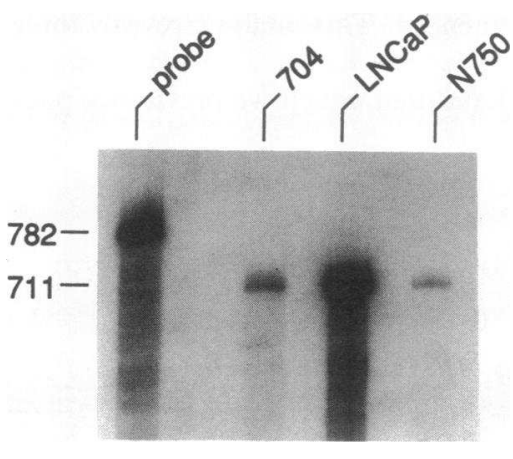

Figure 5. $S_{1}$ nuclease protection analysis of androgen receptor mRNA. Samples of RNA prepared from normal fibroblasts (704), a prostate carcinoma cell line that expresses high levels of androgen receptor (LNCaP), and a mutant (N750) were analyzed by $S_{1}$ nuclease protection using an RNA probe (see Methods) derived from nucleotides $1,850-2,563$ in the cDNA. The undigested labeled probe is indicated to the left. The molecular weight marker sizes are shown to the left in base pairs. 


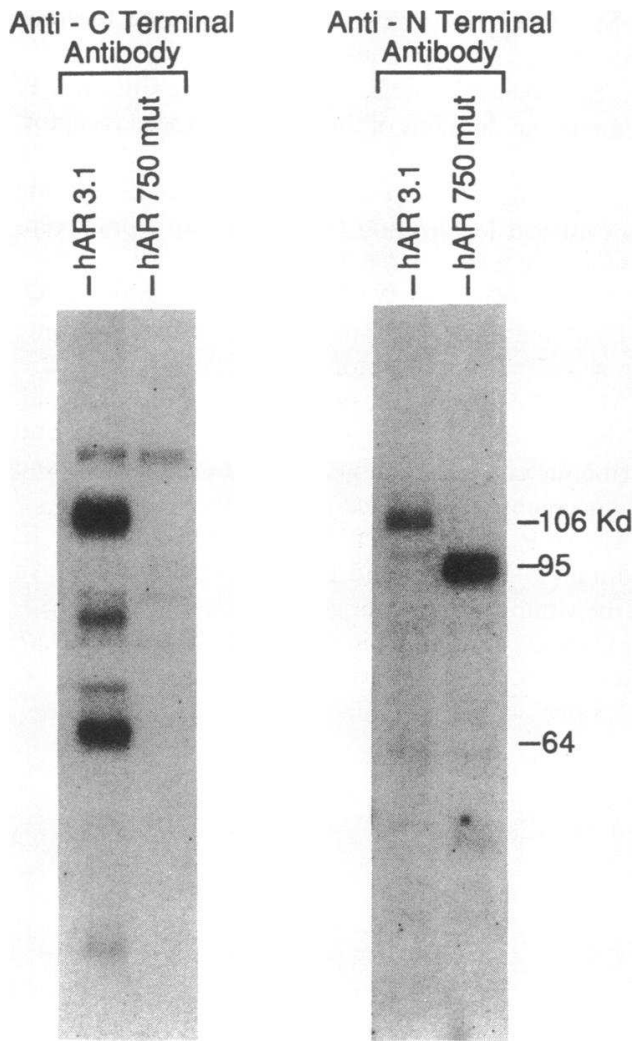

Figure 6. Transfected COS cells produce similar amounts of normal and mutant androgen receptor proteins. Transfected cell cultures from the same experiment analyzed for $\left[{ }^{3} \mathrm{H}\right] 5 \alpha$-dihydrotestosterone binding in Table I were scraped into ice-cold phosphate buffered saline, pelleted, and solubilized in SDS-PAGE-loading buffer $(100 \mathrm{mM}$ dithiothreitol, $2 \%$ SDS, $10 \%$ glycerol, $80 \mathrm{mM}$ Tris pH 6.9). Samples from COS cells transfected with either the normal $(93 \mu \mathrm{g}$ of cell protein) or mutant ( $99 \mu \mathrm{g}$ of cell protein) androgen receptor cDNAs inserted into the expression vector CMV3 were electrophoresed, transferred, and examined by Western analysis using affinity-purified antibodies directed at the amino-(N) terminal 21 amino acids or the carboxyl-(C) terminal 20 amino acids of the androgen receptor protein. Numbers on the right side indicate the size of protein bands as determined by comparison with ${ }^{14} \mathrm{C}$-labeled protein molecular weight markers (Amersham Corp.).

It is likely that mutations causing androgen resistance will encompass a wide range of genetic alterations. The delineation of the underlying genetic defect in other patients with androgen resistance will undoubtedly lead to a better understanding of the functional organization of the androgen receptor and of other steroid receptors as well.

\section{Acknowledgments}

Dr. Marcelli and Dr. Tilley should be considered equal first authors. We thank Brenda Hennis for expert secretarial assistance and Diane Rae Allman for expert technical assistance.

This work was supported by a Basil O'Connor Award from the March of Dimes (grant 5-694), the Medical Life and Health Insurance Medical Research Fund, the Welch Foundation (grant I-1090), a grant from the Perot Family Foundation, a grant from the Culpeper Foundation, and grant DK-03892 from the National Institutes of Health.
Dr. Tilley was a recipient of a C. J. Martin Fellowship from the National Health and Medical Research Council of Australia. Dr. McPhaul is a Culpeper Medical Scholar.

\section{References}

1. Griffin, J. E., and J. D. Wilson. 1989. The androgen resistance syndromes: $5 \alpha$-reductase deficiency, testicular feminization, and related syndromes. In The Metabolic Basis of Inherited Disease. 6th ed. C. R. Scriver, A. L. Beaudet, W. S. Sly, and D. Valle, editors. McGraw-Hill Inc., New York. 1919-1944.

2. Tilley, W. D., M. Marcelli, J. D. Wilson, and M. J. McPhaul. 1989. Characterization and expression of a cDNA encoding the human androgen receptor. Proc. Natl. Acad. Sci. USA. 86:327-331.

3. Lubahn, D. B., D. R. Joseph, M. Sar, J. Tan, H. N. Higgs, R. E. Larson, F. S. French, and E. M. Wilson. 1988. The human androgen receptor: complementary deoxyribonucleic acid cloning, sequence analysis and gene expression in prostate. Mol. Endocrinol. 2:12651275.

4. Chang, C., J. Kokontis, and S. Liao. 1988. Structural analysis of complementary DNA and amino acid sequences of human and rat androgen receptors. Proc. Natl. Acad. Sci. USA. 85:7211-7215.

5. Trapman, J., P. Klassen, G. G. J. M. Kuiper, J. A. G. M. van der Korput, P. W. Faber, H. C. J. van Rooij, A. G. van Kessel, M. M. Voorhorst, E. Mulder, and A. O. Brinkman. 1988. Cloning, structure, and expression of a cDNA encoding the human androgen receptor. Biochem. Biophys. Res. Commun. 153:241-248.

6. Brown, T. R., D. B. Lubahn, E. M. Wilson, D. R. Joseph, F. S. French, and C. J. Migeon. 1988. Deletion of the steroid binding domain of the human androgen receptor gene in one family with complete androgen insensitivity syndrome: evidence for further genetic heterogeneity in this syndrome. Proc. Natl. Acad. Sci. USA. 85:81518155.

7. Hurt, W. G., J. N. Bodurtha, J. B. McCall, and M. M. Ali. 1989. Seminoma in a pubertal patient with androgen insensitivity syndrome. Am. J. Obstet. Gynecol. 161:530-531.

8. Leshin, M., J. E. Griffin, and J. D. Wilson. 1978. Hereditary male pseudohermaphroditism associated with an unstable form of $5 \alpha$ reductase. J. Clin. Invest. 62:685-691.

9. Wiger, M., R. Sweet, G. K. Sim, B. Wold, A. Pellicer, E. Lacy, T. Maniatis, S. Silverstein, and R. Axel. 1979. Transformation of mammalian cells with genes from prokaryotes and eukaryotes. Cell. 16:777-785.

10. Chirgwin, J. M., A. E. Przybyla, R. J. McDonald, and W. J. Rutter. 1979. Isolation of biologically active ribonucleic acid from sources enriched in ribonuclease. Biochemistry. 18:5296-5299.

11. Church, G. M., and W. Gilbert. 1984. Genomic sequencing. Proc. Natl. Acad. Sci. USA. 81:1991-1995.

12. Saiki, R. K., D. H. Gelfand, S. Stoffel, S. J. Scharf, R. Higuchi, G. T. Horn, K. B. Mulus, and H. A. Erlich. 1988. Primer directed enzymatic amplification of DNA with a thermostabile DNA polymerase. Science (Wash. DC). 239:487-491.

13. Kaiser, K., and N. E. Murray. 1985. The use of phage lambda replacement vectors in the construction of representative genomic DNA libraries. In DNA Cloning. D. M. Glover, editor. Vol. I. IRL Press, Washington, DC. S1-47.

14. Sanger, F., S. Nicklen, and A. R. Carlson. 1977. DNA sequencing with chain-terminating inhibitors. Proc. Natl. Acad. Sci. USA. 74:5463-5467.

15. Burke, J. F. 1984. High sensitivity $S_{1}$ mapping with single stranded ${ }^{32}$ P]DNA probes synthesized from bacteriophage M13 mp templates. Gene (Amst.). 30:63-68.

16. Chu, G., H. Hayakawa, and P. Berg. 1987. Electroporation for the efficient transfection of mammalian cells with DNA. Nucleic Acids Res. 15:1311-1326. 
17. Griffin, J. E., and J. D. Wilson. 1977. Studies on the pathogenesis of the incomplete forms of androgen resistance in man. J. Clin. Endocrinol. Metab. 45:1137-1143.

18. Lowry, O. H., N. J. Rosebrough, A. L. Farr, and R. J. Randall. 1951. Protein measurement with the Folin phenol reagent. J. Biol. Chem. 193:265-268.

19. Laemmli, U. K. 1970. Cleavage of structural proteins during the assembly of the head of bacteriophage T4. Nature (Lond.). 227:680-686.

20. Harris, B. A., J. D. Robishaw, S. M. Mumby, A. G. Gilman. 1985. Molecular cloning of complementary DNA for the alpha subunit of the $\mathrm{G}$ protein that stimulates adenylate cyclase. Science (Wash. DC). 229:1274-1277.

21. Green, N., H. Alexander, A. Olson, S. Alexander, T. M. Shinnick, J. G. Sutcliffe, and R. A. Lerner. 1982. Immunogenic structure of the influenza virus hemagglutamin. Cell. 28:477-487.

22. Faber, P. W., G. G. J. M. Kuiper, H. C. J. van Rooij, J. A. G. M. van der Korput, A. O. Brinkman, and J. Trapman. 1989. The N-terminal domain of the human androgen receptor is encoded by one large exon. Mol. Cell. Endocrinol. 61:257-262.
23. Evans, R. M. 1988. The steroid thyroid hormone receptor superfamily. Science (Wash. DC). 240:889-895.

24. Kumar, V., S. Green, G. Stack, M. Berry, J.-R. Jin, and P. Chambon. 1987. Functional domains of the human estrogen receptor. Cell. 51:941-951.

25. Picard, D., and K. R. Yamamoto. 1987. Two signals mediate hormone-dependent nuclear localization of the glucocorticoid receptor. EMBO (Eur. Mol. Biol. Organ.) J. 6:3333-3340.

26. Hollenberg, S. M., V. Giguere, P. Segui, and R. M. Evans. 1987. Colocalization of DNA-binding and transcriptional activation functions in the human glucocorticoid receptor. Cell. 49:39-46.

27. Danielsen, M., J. P. Northrup, J. Jonklass, and G. M. Ringold. 1987. Domains of the glucocorticoid receptor involved in specific and nonspecific deoxyribonucleic acid binding, hormone activation, and transcriptional enhancement. Mol. Endocrinol. 1:816-822.

28. Ritchie, H. H., M. R. Hughes, E. T. Thompson, P. J. Malloy, Z. Hochberg, D. Feldman, J. W. Pike, and B. W. O'Malley. 1989. An ochre mutation in the vitamin $D$ receptor gene causes hereditary 1,25 dihydroxyvitamin $\mathrm{D}_{3}$-resistant rickets in three families. Proc. Natl. Acad. Sci. USA. 86:9783-9787. 